\title{
Current State and Development Trends of Agrarian Labor Market
}

\author{
Larionova N.P. \\ Northern Trans-Ural State Agricultural University \\ Tyumen, Russia \\ e-mail: Larionova_n_p@mail.ru
}

\begin{abstract}
Agroindustrial complex is a key sector of economy providing food security of the region and the country. One of the factors worsening food security is constant and increasing personnel shortage. The article studies the issues of developing federal and regional labor market. The methodology of the research consists of two parts. The first is devoted to the macro and micro levels of the market labor implementation. Labor market models used in the world practice have been generalized. Novelties in the population employment have been determined. The personnel need has been analyzed, workers' release in the municipal units in the regions, by the branches and work groups have been studied. Factors influencing favoring personnel providing in the industry have been determined. The state gives financial support to agricultural good producers. The second part of the article studies forms, kinds, methods and scopes of the state support to the human resourcing in the region. The influence of state support for personnel in AIC on the labor supply has been estimated. The changes in dynamic of the state support have been estimated. The conclusion has been made about the importance of the state support for the personnel in developing regional agrarian labor market. The research determines the key elements for motivating highly qualified specialists in AIC. The priorities for the labor market development in the region have been determined. The results are the basis for the management making in AIC, including the Tyumen region.
\end{abstract}

Key words - AIC, agrarian labor market, personnel estimating, human resourcing, state support, development.

\section{INTRODUCTION}

Labor market is a component of the market economy which functions together with other markets: raw materials, commodity goods and services, accommodation, value documents and other markets.

Different aspects of the labor market, together with the agrarian one, have been studied in the works of the following authors: L.G. Agapitova, I.V. Bushmarina, Vasilchuk, E.D. Vilkhovchenko, A.I. Voropaeva, M.V. Dronova, A.V. Kashepova, A.A. Mertsalova, V.A. Pavlenkova, E.R. Sarukhanova, T.I. Sorokina, L.Sosnovskaya, V.Ya. Malakhova, V.F. Mashenkova, B.P. Pankova, A.V. Petrikova, V.V. Pechenkina, E.S. Stroeva, A.M. Ugayai and others.

Ushachev I. in the article "Main trends of the sustainable social-economic development of AIC in Russia" discusses the issue of the agrarian labor market as one of the trends of AIC socio-economic development in Russia. [16].
Labor market is a system of social relations connected with employment. The price for labor force is salary.

In Russia the labor market is implemented via:

1. The public employment service

2. The commercial employment service

Types of non-state employment service:

- Employment agencies (hiring hall), working with the population. In this case, people determine the criteria of their working place, pay for the agency service according to the price list. The agency in its turn should find a working place for a client according to his/her qualifications and personal data.

- Recruitment agencies search, estimate and choose the personnel according to the employer requirements. The employment for the applicants is not guaranteed, their data will be found by the request. As a rule, these agencies take payment from the employer. For population their service is free.

- The agencies combining the functions of the employment agencies and recruitment agencies.

3. Recruitment agencies of the enterprises and establishments;

4. Negotiations between the employer and the employee.

Labor market segmentation is division of workers and working places into steady sectors, zones which restrict the working force mobility by their boundaries.

The segmentation characteristics can be:

- localization: region, state, district;

- demographic characteristics: age, sex, marital status;

- socio-economic characteristics: education; professional qualification of workers; length of work;

- economic characteristics: employers' classification by ownership, financial state; sellers' distribution by material status and other;

- behavioral response: employment motivation and other; 
- psychophysiological criteria: personal qualities of employees, their affiliation with a certain population stratum.

New phenomena in the population employment: labor market segmentation by the ownership and status of employment, informal labor sector development, small business and other.

All people employed nowadays can be divided into three groups:

- employed in a formal, state sector,

- employed in a formal private sector,

- employed in an informal sector.

The informal sector is an activity in the sphere of goods and services which allows receiving additional working places and income. Its characteristics can help draw a parallel between the informal sector and the shadow economy. In the first case the motives for participating is survival (when there is no other job), desire to be independent and have a flexible schedule, in the second case the motives are receiving excess profit, concealing high income from the state or illegal activities (for example, drug production).

There are the following labor market models in the world:

- The USA labor market is characterized with high activity of the participants, employment policy at the enterprises, oriented at the high areal mobility of the workers between the enterprises, minimum training costs.

- The Japanese labor market has the system of the "lifelong" employment, guaranteeing employment for the whole period of working activity and forming independent labor unions in the company. When salary is calculated a big attention is paid to the length of service which restricts workers from changing the working place. Age is also taken into account, but at the last years more importance is given to the qualification and labor efficiency.

- Swedish labor market has an active employment policy conducted by the state, using money from the unemployment funds for professional training and retraining, creating working places, both in the state and the private sector by subsidizing private companies, helping the unemployed in the work search, via information and professional consultation, benefits payment for moving to the new place of work, keeping employment in the spheres providing necessary services in the depressed regions.

That is why, the purpose of the article is studying the state and perspectives of the development of the agrarian labor market in Russia and the Tyumen region.

\section{MATERIALS AND METHODS}

The methods consist of two parts. The first is estimating the level of the agrarian labor market development, determining factors favoring provision of the agricultural branch with labor force, studying federal and regional agrarian labor market. The second part estimates the influence of the state support for AIC provision with labor force on the employment. The kinds and forms of the state support for the regional labor force provision have been estimated.

As we have already noted in other articles the state support for the agriculture is an important element of AIC regulating. Its use determines the efficiency of the agricultural production, its development tempos, level of food security, state of agrarian territories. This issue is especially important with Russia's entering WTO, sanctions and import substitution in the country [9].

For the last 15 years, labor markets have been on their own and developed according to the market requirements. Though, in every developed country the state always regulates the labor market, especially agrarian.

The misbalance between the labor requirement and its availability increases both on the federal and regional level.

\section{RESULTS AND DISCUSSION}

The labor market in the Tyumen region and in Russia is influenced by the socio-economic situation in the region, one of which is workers' dismissal due to staff optimization as well as partial employment.

At the same time, the misbalance between the demand and supply of the working force is conditioned by:

- The discrepancy between the employer needs in the staff and the structure of the labor force in the region's market;

- Tightening of the employers' requirements in the present economic situation to the employees' qualification, occupational skills, and work experience;

- Personnel deficiency of workers.

The demographic situation in the region becomes better: in the first quarter of 2018 year the total population of the region increased by $1.4 \%$ comparing with the beginning of 2017 year, and was 1498.8 ths. people. The average value of the unemployment level is about $5.0 \%$ of the work-force size. The occupational level is $62.8 \%$ (in the Russian Federation it is $65.1 \%$, in the Ural Federal District it is $65.7 \%$ ). Comparing with the similar period of the last year the increase was $0.4 \%$.

There are positive tendencies both in the social and economic spheres in the Tyumen region. The amount of investments into the main assets in 2017 was 290.7 bln. rubles. In food production the index was $103.6 \%$. There is an increase in meat and meat processing, fish, vegetables industries, in diary produce, milling, and cereal industries. Positive economic situation in the region stimulates high demands from the employers.

Among the municipal units in the Tyumen region the biggest demand for personnel is in Tyumen, Tobolsk and Tyumen municipal area. The total share of the recruitment needs on the territories in 2018 was $86.4 \%$ of overall need in the region. It is connected with the development of the 
production sphere and the economic structure of these municipal areas, as well as with the implementation of the investment projects on their territories.

Relatively low staffing requirement is in Isetsk area (2\% of the total requirement in the region -531 people), Uvatsk ( $1.7 \%-470$ people), Golyshmanovsk $(0.84 \%-225$ people) and Kazansk (0.79\% - 213 people) municipal areas, in Ishim (1.4\% - 366 people) and Zavodoukovsk city district (1\%274 people). The recruitment need in these municipal areas is mostly in the social area.

The low demand in man power in 2018 was in Sorokinsk district -30 people. In other municipal areas it was at the level $50-180$ people, and aimed at the substitution of the releasing workers.

In long-rate staffing requirement in 2019 there is a slight increase in the personnel demand in Zavodoukovsk city district by 11 people, there will be a further decrease.

In the forecasting period 2018 - 2023 the greatest personnel demand is expected in building - $61.9 \%$; manufacturing activities $-5.1 \%$; wholesale and retail trade $4.8 \%$; municipal administration and defense, social security $4.7 \%$; education and agriculture $-3.4 \%$ and $3.2 \%$ correspondingly; healthcare $(2.8 \%)$ and professional, scientific and engineering sphere $-2.7 \%$.

On the whole, in 2018 the work-force demand in industry and building was 15.3 ths. people. It is highest of the total staffing requirement $-56.7 \%$. The most demand is in workers: installers -4.8 ths. people; welders -1.31 ths. people; stuccos -1.25 ths. people; electrical and gas welders 1.1 ths. people; bricklayers -909 people and concretors -766 people.

Staffing requirement in agriculture is caused by the governmental policy, aimed at growth in production, by supporting collective farms (households), agricultural production cooperatives (mostly buying) and personal subsidiary plots. The total staffing demand in agriculture is 377 people $-1.4 \%$ from the total demand in the region.

In 2018 the proposed workers release was in 108 organizations in the Tyumen region (in 2016 121 organization, in $2015-185$ organizations). The total amount of workers to dismiss was -3586 people.

By 01.06.2018 the part-work mode is used in 34 organizations, in 30 of them the part-time shift (working day) or week has been introduced, in 1 organization the workers are on holiday without pay. It is $2.4 \%$. The biggest part of parttime workers is in manufacturing industry $-58.0 \%$, building $-24.4 \%$. With the estimation and forecast in $2018-2023$ in organizations in the Tyumen region about $3.6-2.4$ ths. people per year will be released. In the municipal areas basing on the estimation of 2018 the biggest dismissal is expected in Tyumen $-53.5 \%$ on the total, in the Zavodoukovskaom city area -220 people and Ishim -213 people.

The work force release is expected in such areas as education, state administration and defense, financial and insurance activity, manufacturing and building, wholesale and retail. By estimating 2018, $72 \%$ of work force release is expected in these areas from the total work release in the region. In the agriculture there is a decrease of work force release. The amount of drivers of different categories and watchmen (keepers) $4.4 \%$ and $4.0 \%$ correspondingly are expected to be dismissed by 2018 .

For the last several years the Tyumen region has had a high investment activity. In 2018 the region became a leader of the National Investment Climate Index. In 2016 it took the $5^{\text {th }}$ place, in 2017 the $6^{\text {th }}$. In 2017,21 investment project has been implemented with creating 3092 of new working places. By the 2025 in the Tyumen region about 8.5 ths. working places in different professions will have been created.

The table below gives information on the amount of the working force in 20 investment projects implemented in the region. Among them 9 projects are at the final stage with the total work force demand about 436 people. In the mid-term about 7 projects are at the final stage. By 2023 it is planned to finish 4 projects.

Calculating the balance of work force offer and demand (table 2) is one of the complex mechanism of human resources control both in an individual company and the region on the whole, the most effective component of the business interaction of regional systems of the professional education and labor market.

TABLE I. STAFFING DEMAND WITHIN THE INVESTMENTS PROJECTS IN THE TYUMEN REGION BY THE COST MORE THAN 300 BLN RUBLES (THE DATA ON THE COMPANIES PARTICIPATING IN THE MONITORING).

\begin{tabular}{|l|l|l|l|l|l|l|l|l|l|}
\hline \multirow{2}{*}{$\begin{array}{l}\text { Investment } \\
\text { project holder }\end{array}$} & \multirow{2}{*}{$\begin{array}{c}\text { Execution } \\
\text { period }\end{array}$} & $\begin{array}{c}\text { Number of } \\
\text { expected } \\
\text { working } \\
\text { places }\end{array}$ & $\mathbf{2 0 1 8}$ & $\mathbf{2 0 1 9}$ & $\mathbf{2 0 2 0}$ & $\mathbf{2 0 2 1}$ & $\mathbf{2 0 2 2}$ & $\mathbf{2 0 2 3}$ \\
\hline $\begin{array}{l}\text { Total for an } \\
\text { investment } \\
\text { project }\end{array}$ & - & - & 789 & 772 & 478 & 371 & 366 & 392 \\
\hline AIC and food industry & & & & & & & & & \\
\hline LLC "Era-98" & $2012-2017$ & 150 & 23 & 23 & 5 & 5 & 0 & 0 \\
\hline $\begin{array}{l}\text { LLC "PRODO } \\
\text { Tyumen } \\
\text { broiler" }\end{array}$ & $2014-2020$ & 500 & 130 & 130 & 148 & 6 & 0 & 0 \\
\hline $\begin{array}{l}\text { LLC "TC } \\
\text { Tyumen Agro" }\end{array}$ & $2013-2019$ & 600 & 0 & 0 & 0 & 0 & 0 & 0 \\
\hline
\end{tabular}

Calculating the ratio of the work force offer and demand in the Tyumen region the data of the current labor market state have been taken into account with the forecasting demand of the organization in the working force with the account of workers' release, investment projects in the region, and data on training specialists by educational establishments.

TABLE II. THE RATIO OF THE WORK FORCE OFFERS AND DEMAND IN THE CORE BUSINESS LINE (AGRICULTURE) 2018 - 2023

\begin{tabular}{|l|l|l|l|l|}
\hline Core business line & Year & $\begin{array}{c}\text { Demand } \\
\text { people }\end{array}$ & $\begin{array}{c}\text { Number of } \\
\text { graduates, } \\
\text { people }\end{array}$ & $\begin{array}{c}\text { The ratio of the work } \\
\text { force offer and demand } \\
\text { ("_-"' demand, "+" } \\
\text { excess) }\end{array}$ \\
\hline $\begin{array}{l}\text { Agrarian, } \\
\text { forestry, hunting, } \\
\text { fisheries and } \\
\text { aquaculture } \\
\text { sectors }\end{array}$ & 2018 & 851 & 1025 & 174 \\
\cline { 2 - 5 } & 2019 & 774 & 1134 & 360 \\
\cline { 2 - 5 } & 2020 & 662 & 1341 & 679 \\
\cline { 2 - 5 } & 2021 & 601 & 1719 & 1118 \\
\cline { 2 - 5 } & 2023 & 543 & 1483 & 940 \\
\hline
\end{tabular}


An excess of the work force is expected in the forecasting period; the number of graduates is greater than the number of the working places. There is another important - issue work holding the graduates in the village.

The ratio of the work force offer and demand in professions and specialties reflects further professions where the greatest demand for workers is expected: Technician, Mechanical engineer, Electric and gas welder, Painter, Electrician, Insulation worker, Gas welder, Outer line constructor, Sanitary engineering systems and equipment constructor, Wiring system circuit installer, Electrician, Wire fixer and others.

Measures aimed at the employment promotion are fulfilled by the employment agencies for the population in the Tyumen region by implementing the governmental program of the Tyumen region "Basic development trends in the employment promotion, labor and other labor relations" till 2020, approved by the decision of the Government on 22.12.2014 N 651-p. The basic aim of the program is the employment promotion, human resource development in the region, raising the living standards.

To satisfy the demand in the work force in the region the employment agencies in the Tyumen region organize professional training and retraining of the unemployed. Also, there are a lot of courses for the entrepreneurship.

Medvedeva L.B. estimates the efficiency of man power utilization in the small and middle segments of household. [11-13].

The group of authors with Kozlov A. In the article "Agrarian labor market: old problems, new challenges", among the factors depriving food security in Russia determines permanent and increasing shortage of agricultural personnel. The authors note that to overcome negative factors various socio-economic mechanisms have been suggested to increase labor efficiency, work-holding the youth in the countryside, training and increasing qualification, increase in salary and income for the rural population, improving socioeconomic conditions for their living [7].

Medvedeva L.B., Agapitova L.G. and others in the article on the labor behavior of the personnel determine 18 motives for labor behavior, some of them are determined by the economic situation at the enterprise, the others - by the inner situation at the enterprise, including managerial aspects, labor management.

Analyzing the results of the research allowed making the following conclusions:

- when forming the motivation mechanism of the organization the degree of workers' motivation is of great importance, as people motivated for success make long-term plans (expectation theory);

- universal human values and morality are very important;

- inner motivation, or internal necessity to work is more important for the respondents and determined by some external motivations (awareness degree and clear motivation object, expected result, challenge character, independence, object attractiveness, regularity, efficiency record adequacy) [8].

The state fulfils a complex of measures to attract personnel into the village. In the Tyumen region such kinds of support as one-time payments to the graduates, Governor grants to young managers and specialists, advanced training for managers and specialists, improving housing conditions for young specialists and their families are implemented [10].

Butorina G.U. together with the group of authors in the article "Basic principles of the evolutional doctrine in economics" notes that "inter-industry relations in economics, if consider the household sector as economic organizations, are varied and complicated. The relations based on the technological chains of manufacturing final products or technological distributions are of great importance. These redistributions create different cooperative, integrated relations between the household subjects in product delivery to each other, forming corporations and so on. Between holdings, branches and individual enterprises there are competitive relations to take hold of market places. In some cases, there are rival relations between different enterprises and their corporations, in some - less competitive, in others cooperative [14].

In the works by Butorkina G.U. the issues of new forms of the state support have been disclosed. They are aimed at the creation and functioning of farms as one of the factors influencing the development of the agrarian territories, solving problems of the village youth [2-5].

New forms of support are constantly introduced into AIC. They help create new working places and villagers' employment. First of all, they support small households:

- Grant to support a starting farmer;

- Grant "Agrostartup";

- Grant for household animal farms;

- Subsidies for agricultural consumer cooperatives;

- Grant for developing material and technical base to agricultural consumer cooperatives.

\section{CONCLUSION}

Basing on the foregoing, the following recommendations can be formulated to achieve the balance on the labor market in the Tyumen region (without autonomous areas):

- To popularize working professions via competitions in professional skills at regional, national and international levels, as well as organizing competitions as the tool for competitive recovery of young specialists and educational establishments.

- Constantly give methodic and methodological support to schools in professional identity of students within career days - conduct thematic competitions, popularizing certain professions which will be in demand in the long run. 
- To increase interaction of educational establishments and applicants with enterprises, that will allow creating educational resources on the basis of innovational and industrial activity (material-technical base, methodic, educational modules), provide their integration into the educational processes of higher and vocational training as well as additional vocational training.

- At the regional level organize measures to attract graduates to the priority sectors of economy and determining the perspective employer. These measures can include support of prospective employers in new specialists' training via participating in educational programs, developing the common regional system of internship, career fairs and graduates' meetings.

- To support small businesses with employees and citizens in setting up their business, including rural areas, by creating service enterprises, small enterprises on processing local raw materials.

- With the account of the demographic situation and the pension reform the accent in the system of education should be aimed at raising the qualification level of workers, especially of the older age, as they are one more category who can satisfy the need of economy in qualified personnel.

To increase market transparency and with the account of the vast regional vacancies base to form single $\mathrm{CV}$ base of people looking for a job. This information will increase the efficiency of search of suitable employees, but will give additional information to increase the quality of labor market monitoring. Priority tasks for the labor market development in the region:

- Increasing labor market flexibility and managing.

- Creating conditions for areal and professional mobility of people.

- Supporting self-employment of people especially in rural areas by creating service enterprises, small enterprises on processing local raw materials.

- Creating new working places with high efficiency of labor.

- System development for adaptation of unemployed people and dismissed workers, their retraining.

- Increasing efficiency of vocational training and retraining of workers by developing the system of training, retraining, and personnel development including internal training.

- Popularizing and propaganda of blue-collar jobs.

- Creating conditions for priority utilization of local labor.

- Active support of small business in staffing.
Thus, the conducted research has determined the key elements of motivating and attraction of highly qualified specialists in AIC. The priority tasks for the perspective development of labor market in the region have been determined. The results are the bases for managerial decisions in AIC of the Tyumen region.

\section{References}

[1] L.G. Agapitova, "Labor resources at the agricultural enterprise: analytical aspect of the labor payment", J. of econ. and entrepreneurship, № 9-2 (86). pp. 623-626, 2017.

[2] G.U. Butorina, "Developing agricultural territories as a factor solving the problems of the rural youth", Agrar. policy of Russ., vol. 5, no. 41, pp. 28-31, 2015.

[3] G.U. Butorina, "Grant state support of the starting farmers in the Tyumen region”, Financial econ., no. 3, pp. 719-723, 2019.

[4] G.U. Butorina, "Characteristics of a new state support aimed at the development of farm households in the region", Financial econ., no. 8, pp. 225-229, 2019.

[5] G.U. Butorina, "State support of farm households in the region", Financial econ., no. 10, pp. 362-365, 2019.

[6] M.V. Dronova, T.I. Sorokina, "Estimating the living standards of the rural population in the south of the Tyumen region", Agrar. policy of Russ., vol. 4, no. 52, pp. 29-32, 2016.

[7] A. Kozlov, B. Pankov, O. Yakovleva, "Agrarian labor market: old problems new challenges", AIC: econ. and manag., no. 4, pp. 32-36, 2016.

[8] N.G. Khairulina, O.V. Ustinova, G.V. Kuhterina, L.G. Agapitova, L.B. Medvedeva, "Set of value in the structure of labor behavior of personnel”, MII-MII(-SP), Man In India, vol. 96, no. 10, pp. 3957-3968, 2016. (ISSN00251569-India-Scopus). Retrieved from: http://serialsjournals.com/articles.php?volumesno_id=1105\&journals_id =40\&volumes_id=836 (date of refference: 14.11 .2019 ).

[9] N.P. Larionova, "Govermment support of agriculture and evaluation of its effectiveness at the macro and micro level", 18-19 April 2019 [Conf. on Innovat. in Agricult. and Rural development]. Kurgan, no. 01221. Retrieved from: https://iopscience.iop.org/issue/1755-1315/341/1 https://iopscience.iop.org/article/10.1088/1755-1315/341/1/012211

[10] N.P. Larionova, "State support for staffing AIC in the Tyumen region", J. of econ. and entrepreneurship, no. 9, pp. 1090-1094, 2017.

[11] L.B. Medvedeva, "Analysis of the labor resources efficiency at the agrarian enterprises of the Tyumen region", J. of econ. and entrepreneurship, vol. 9-1, no. 86, pp. 986-988, 2017.

[12] L.B. Medvedeva, "Small enterprises as a condition of economic stability in the challenge society", J. of econ. and entrepreneurship, vol. 10, no. 99, pp. 771-773, 2018.

[13] L.B. Medvedeva, "Projecting the system of personnel management at a small enterprise", J. of econ. and entrepreneurship, vol. 1, no. 102 , pp.729-732, 2019

[14] I. Nusratullin, O. Yeremeeva, G. Butorina, S. Novikov, M. Kovazhenkov, "The main provisions of the evolutionary doctrine in economics", Amazonia Investiga, vol. 9, no. 25, 230-241, 2020. Retrieved from: https://www.amazoniainvestiga.info/index.php/ amazonia/article/view/1062

[15] T.I. Sorokina, "Rural settlement: modern state, challenges, perspectives of the economy development", J. of econ. and entrepreneurship, vol. 12-2, no. 89, pp. 122-127, 2017.

[16] I. Ushachev, "Main trends of the strategy for sustainable socio-economic development of AIC in Russia", AIC: econ., manag., no. 6, pp. 4-24, 2017. 